Research article

\title{
Floristic assessment of different habitats of Parvati Aranga wildlife sanctuary and adjacent Tikri forest area, Gonda, Uttar Pradesh, India
}

\author{
Vineet Singh $^{1^{*}}$, S. K. Srivastava ${ }^{2}$ and L. M. Tewari ${ }^{3}$ \\ ${ }^{1 *}$ Botanical Survey of India, Central Regional Centre, Allahabad, Uttar Pradesh, India \\ ${ }^{2}$ Botanical Survey of India, Northern Regional Centre, Dehradun, Uttarakhand, India \\ ${ }^{3}$ Department of Botany, DSB Campus, Kumaon University, Nainital, Uttarakhand, India \\ *Corresponding Author: vineet.singh332@gmail.com \\ [Accepted: 20 October 2016]

\begin{abstract}
The Parvati Aranga wildlife sanctuary and adjoining Tikri reserve forest in northeastern Terai region of Uttar Pradesh with its varied ecological habitats and occurrence of patchy wetlands in form of 'River' and 'Tals' sustains a variety of plant communities. The area also harbours a rich diversity of economical and medicinal plant species, mainly confined to the peripheral region of the forest. A large component of the forest is occupied by diverse forest stands and a number of special habitats portray remarkable vegetational diversity. The present communication reveals that the plant community with special habitat especially in protected and reserve forest area may plays a vital role in the future sustenance of the forest vegetation. Rarity and regeneration pattern of the flora is also discussed.
\end{abstract}

Keywords: Plant community - Special habitats - Terai region.

[Cite as: Singh V, Srivastava SK \& Tewari LM (2016) Floristic assessment of different habitats of Parvati Aranga wildlife sanctuary and adjacent Tikri forest area, Gonda, Uttar Pradesh, India. Tropical Plant Research 3(3): 543-550]

\section{INTRODUCTION}

The comprehension of relationship between plants and environmental factors can be used as an indicator of environment, in this context a number of plants species used as ecological indicators. In a plant community some plants are dominant and found in abundance, these are important markers because they bear full impact of surroundings. In general, plant communities are better indicators than individual plants and are used to determine the types of soil and other conditions of the environment in a given area. Sometimes these also indicate past or future conditions of the environment. Community structure and composition with special habitats immensely affects the plant diversity pattern in any forest area in terms of the sustenance of a particular community.

Forest composition, community structure and diversity pattern are important ecological attributes significantly correlated with prevailing environmental as well as anthropogenic variables (Gairola et al. 2008). The region free from anthropogenic disturbances continues to provide a platform for the microhabitats for an array of local floral elements Wildlife protected areas in India have had a relatively long history of forest management and exploitation as majority of these areas were originally reserved or other categories of government owned forests where focus on management was timber production, meeting the biomass demands of local communities or soil or water conservation (Rodgers \& Sawarkar 1988). The special habitats of any forest plays a key role for the state of natural or reserve forest in the area and to suggest conservation measures for the concerned elements.

The Terai expanse of eastern Uttar Pradesh is an assortment of human settlement, cultivation fields, natural and semi-natural vegetations comprising of grasslands and forests. In this area most of the primary forests have been substituted by economically and commercially important plants particularly tree species and agricultural fields (Bajpai et al. 2012a). This landscape is listed among the important ecoregions of the world, well known 
for its unique biodiversity and productivity (Tripathi \& Singh 2009). The region is an ecotone between bhabar tract of foot hills of Himalayas and the Gangetic plains (Bajpai et al. 2015a). Several authors have dealt with the vegetation of Terai region of the state (Panigrahi et al. 1969, Maliya 2007, Bajpai et al. 2015a, Kumar et al. 2015) and recently some authors also explored the ecological parameters of some forests of the region (Pandey \& Shukla 2003, Chauhan et al. 2008, Behera et al. 2012, Bajpai et al. 2012b, Bajpai et al. 2015b). However the baseline data related to typical vegetation community of the Parvati Aranga wildlife sanctuary (PAWS) has not been documented yet. Thus, this communication deals with the species composition and indicator taxa with special habitats of PAWS.

\section{MATERIALS AND METHODS}

The Study Area, biota and Climate

The study was conducted in Parvati Aranga wildlife Sanctuary (PAWS) and adjacent Tikri forest area at a $26^{\circ} 48^{\prime}-27^{\circ} \mathrm{N}$ longitude and $81^{\circ} 37^{\prime}-82^{\circ} 37^{\prime} \mathrm{E}$ latitude located in Gonda district of north-east Uttar Pradesh (Fig. 1). It is established in 1990, spread over an area of $10 \mathrm{~km}^{2}$ of total $80 \mathrm{~km}^{2}$ area and remaining $70 \mathrm{~km}^{2}$ is of the reserve forest area characterized by typical terai landscape. The sanctuary harbours a rich floral and faunal diversity and is the home for many rare and migratory avifaunas (Singh 2015). The reserve forest is dominated by Shorea robusta as climax species along with other tree species viz. Haldina cordifolia (Roxb.) Ridsdale, Syzygium cumini (L.) Skeels, S. salicifolium (Wight) J. Graham, Tectona grandis L.f., Acacia catechu (L.f.) Willd., Streblus asper Lour., Aegle marmelos (L.) Correa, Madhuca longifolia (J. Koenig ex L.) J. F. Macbr., Barringtonia acutangula (L.) Gaertn., Ficus racemosa L. etc. Understorey species were represented by Clerodendrum serratum (L.) Moon, C. infortunatum L., Mallotus philippensis (Lam.) Muell. Arg., Glycosmis pentaphylla (Retz.) DC. and Carrisa spinarum L. accompanied with climbers and lianas viz. Ichnocarpus frutescens (L.) W.T.Aiton, Tiliacora racemosa Colebr., Bauhinia vahlii Wight \& Arn., Cissampelos pareira L. var. hirsuta (Buch. Ham. ex DC.) Forman, Cocculus hirsutus (L.) W. Theob., Abrus precatorius L., Tinospora cordifolia (Willd.) Hook. f. \& Thompson.

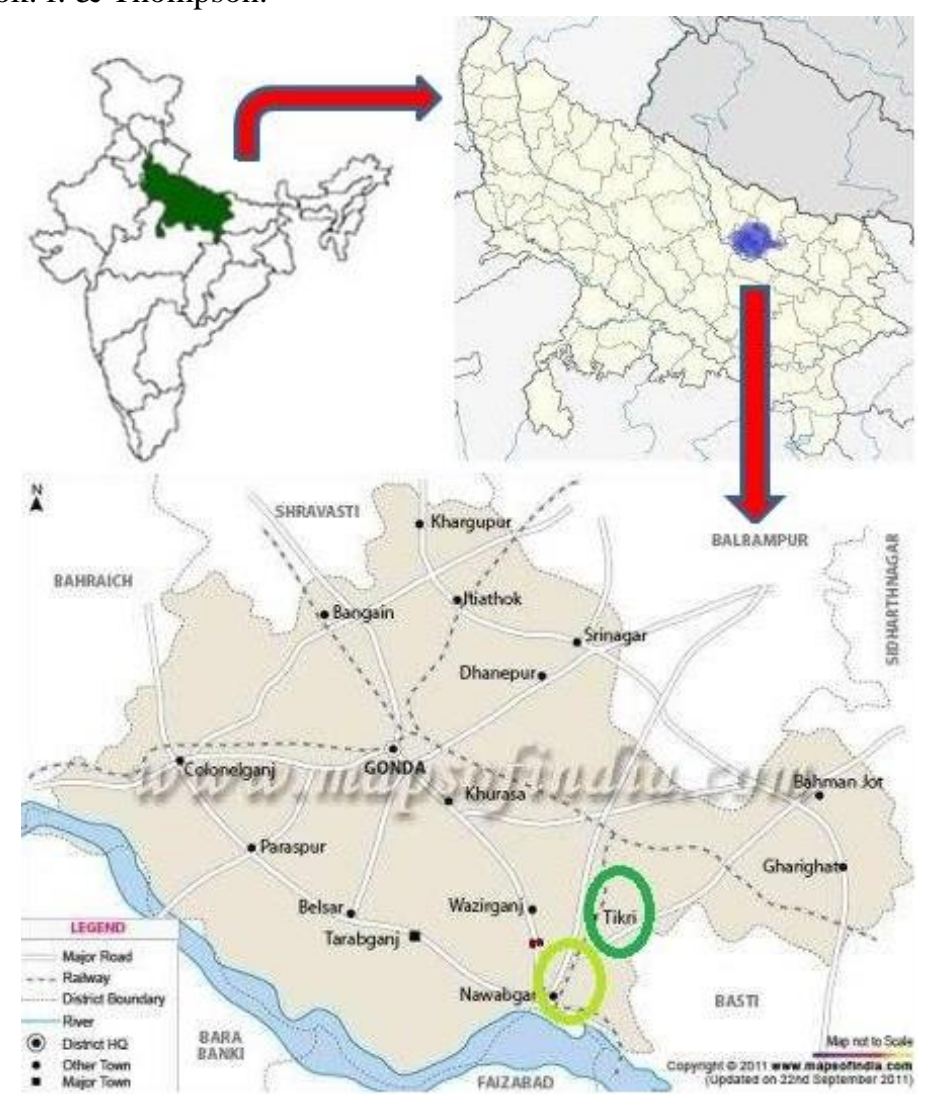

Figure 1. Location of the study area i.e. Parvati Aranga wildlife sanctuary and Tikri forest area, Gonda.

Along with affluent flora the reserve forest is also endowed with many mammalian fauna viz. Wild boar (Sus scrofa), spotted deer (Axis axis), blue bull (Boselaphus tragocamelus), Indian porcupine (Hystrix indica), Rhesus macaque (Macaca mulata) and grey langur (Semnopithecus ajax) with many reptilian species viz. www.tropicalplantresearch.com 
Bengal monitor (Varanus benghalensis), Indian Cobra (Naja naja), Krait (Bungarus caeruleus), Rat snake (Ptyas mисоsa) and Indianpython (Python molurus). The wildlife sanctuary consists of a large wetland in form of lake, rich in avifaunal diversity and different species of fishes. The area also harbours manyrare, threatened and common native and migratory bird viz. Black drongo (Dicrurus macrocercus), Green bee eater (Merops orientalis), Red- wattled Lapwing (Vanellus indicus), Purple swamphen (Porphyrio porphyrio), Sarus crane (Grus antigone), Pied kingfisher (Ceryle rudis), Grey headed fish eagle (Ichthyophaga ichthyaetus) and Red vented Bulbul (Pycnonotus cafer) along with many other species. The people residing near by the sanctuary and the reserve forest are mainly depend upon the natural resources such as fuel wood, fodder, thatched grass and Non- timber forest products for their livelihood and for sacred rituals (Singh \& Srivastava 2014). The area is also rich in many medicinal and economically valuable angiosperms and pteridophytes (Singh \& Srivastava 2015).

The climate is typical monsoon type with three different season's viz. summer (March-June), Rainy (JulySeptember) and winter (October-February). Mean annual rainfall is about $1240 \mathrm{~mm}$. The driest month is November with $2 \mathrm{~mm}$ of rain. The greatest amount of precipitation occurs in July with an average of $356 \mathrm{~mm}$. May is the warmest month of the year; the average temperature is about $34^{\circ} \mathrm{C}$ during this month. The lowest temperature in the year occurs during January it measures around $15.5^{\circ} \mathrm{C}$. The forest of the area have been classified as Eastern Heavy Alluvium plains Sal forest with some part located along the river in swampy areas fall under 4D/SS2- Barringtonia swamp forests and 4D/SS2- Syzygium cumini swamp low forests (Champion \& Seth 1968).

During the course of exploration (2014-2016), the various ecological habitats were visited in different seasons of the year and the dominant species growing in different communities, which act as a keystone species with special importance as indicator, have been collected randomly along with their field data, dried, preserved and mounted by following the standard herbarium techniques (Jain \& Rao 1977-78). These plant specimens were finally identified with the help of floras (Hooker 1872-1897, Duthie 1903-1929) assisted by matching with herbarium specimens for authentication and deposited in BSA and the correct nomenclature of the plants has been provided after consulting recent floras and website like IPNI and The PLANTLIST. The vegetation of the area was observed under different categories viz. top canopy tree species, under-storey, ground flora, lianas and climbers. The relevant information regarding habit, habitat, relative abundance, association, flowering, period, GPS data etc. were collected in the field.

\section{RESULTS AND DISCUSSION}

There are certain plant species which portrays the nature and disposition of habitats commonly referred to as plant indicator. It is found that certain species have one or more specific requirements which may limit their distribution and the occurrence, character and behavior of a plant are thus indicator of the combined effect of all factors prevailing in a habitat. These plant species establish themselves according to their environmental requirement where conditions are favourable. The knowledge of relationship between plants and ecological factors can be used as an indicator of environment. The characteristic species are collectively the best indicators of ecological conditions of the community (Braun-Blanquet 1932). The plants are admittedly a measure of the environment and although the community indicates the nature of the surroundings, only a few key species which are restricted to their habitats are of special importance (Santapau 1958a).

The indicator implication of one group of plants must be inferred and applied to an entirely different group of plants. Generally, forest indicators are herbs or shrubs as compared to trees. In the broad sense, forest indicators are site indicators, but rarely do they suggest more than a portion of the several factors that contribute to site. Some plants indicate the characteristic types of forest and they grow in an area which is not disturbed. Narenga porphyrocoma is a grass which binds the soil in which sal (Shorea robusta) can be cultivated. Viola species in eastern Himalayas is a suitable indicator for plantation of Cedrus deodara and Pinus wallichiana. If we know that a particular forest grows better in certain area of specific soil the productivity can be increased. Physical or chemical characteristics of soil moisture relationships, aeration or erosion may be indicated by some species.

The nature and composition of flora is manifestation of their cumulative effects of all aspects functioning in a particular habitat. It is usually accepted that a set of species or a whole community is steadier as an indicator than a solitary species and that dominants, particularly of the climax species are more useful indicators than lesser species. Species which are less tolerant to many varying conditions are usually indicators since their www.tropicalplantresearch.com 
growth requirements are exacting hence, the dominant species from different communities of selected habitats, are of special importance as indicators of the nature of habitat. The vegetation of the area can be broadly classified in to two grops consisting of various types of plant associations, A. Common vegetation and B. Vegetation of special habitats.

\section{A. Common Vegetation}

The common vegetation of the study area is of moist deciduous type with some evergeen and semi-evergreen tree species. The flora under this category dominates the physiognomy of the forest area by forming different phytoassociations which ultimately leads to a healthy forest in this terai region. Some of the important plant associations (Fig. 2) are discussed below.

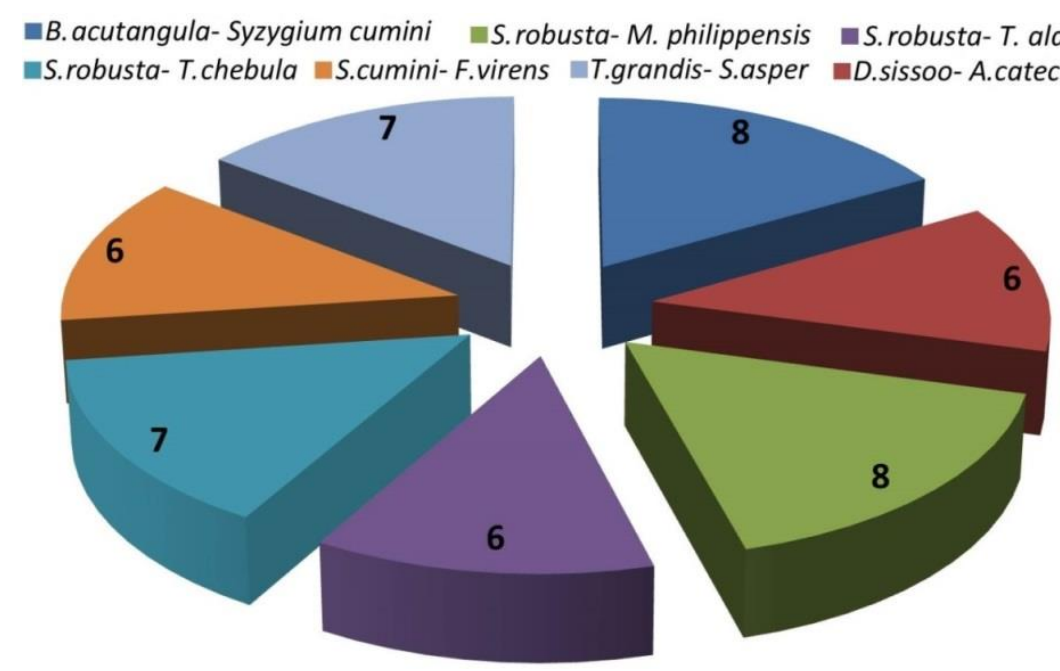

Figure 2. Number of important plant associates in general vegetation community.

1. Shorea robusta - Mallotus philippensis community: Under this category the other associates are Bridelia retusa (L.) A.Juss., Carrisa spinarum L., Rotheca serrata (L.) Steane \& Mabb., Clerodendrum infortunatum L., Curculigo orchioides Gaertn., Ceriscoides turgida (Roxb.) Tirveng., Glycosmis pentaphylla (Retz.) DC. and Haldina cordifolia (Roxb.) Ridsdale.

2. Shorea robusta - Terminalia chebula Community: The other important associates are Aegle marmelos (L.) Correa, Desmodium gangeticum (L.) DC., Phyllodium pulchellum (L.) Desv., Diospyros montana Roxb., Bauhinia vahlii Wight \& Arn., Tiliacora racemosa Colebr. and Oplismenus compositus (L.) P. Beauv.

3. Tectona grandis - Steblus asper community: The other important co-existing species are Abrus precatorius L., Alangium salvifolium (L.f.) Wangerin, Cissampelos pareira L. var. hirsuta (Buch.-Ham. ex DC.) Forman, Dioscorea bulbifera L., Cocculus hirsutus (L.) W. Theob., Clerodendrum infortunatum L. and Elephantopus scaber $\mathrm{L}$.

4. Shorea robusta - Terminalia alata community: The other phytoassociates are Abutilon indicum (L.) Sweet, Oroxylum indicum (L.) Kurz., Ailanthus excelsa Roxb., Sida cordata (Burm.f.) Borss. Waalk., Madhuca longifolia (J. Koenig. ex. L.) J.F.Macbr. and Chrysopogon zizanoides (L.) Roberty.

5. Dalbergia sissoo - Acacia catechu community: The other phytoassociates are Ailanthus excelsa Roxb., Albizia procera (Roxb.) Benth., Ampelocissus latifolia (Roxb.) Planch., Kydia calycina Roxb., Abrus precatorius L. and Cardiospermum halicacabum $\mathrm{L}$.

6. Barringtonia acutangula - Syzygium spp. association: In this type of association there may be individual stands of these species or mixed stands at some places. Syzygium cumini (L.) Skeels and S. salicifolium (Wight) J. Graham. are two important species of syzygium in the study area. The other associates are Calamus tenuis Roxb., Saccharum spontaneum L., Oxystelma secamone K. Schum., Tiliacora racemosa Colebr., Smilax zeylanica L., Helminthostachys zeylanica (L.) Hook., and Lygodium flexuosum (L.) Sw.

7. Syzygium spp. - Ficus spp. association: Mainly consists of Syzygium cumini (L.) Skeels and S. salicifolium (Wight) J. Graham. of Syzygium and Ficus racemosa L., F. heterophylla L.f. and F. virens Aiton. Other phytoassociates are Pongamia pinnata (L.) Pierre, Terminalia arjuna (Roxb. ex DC.) Wight \& Arn. and Vitex negundo $\mathrm{L}$. 


\section{Aquatic flora}

The common habitations of the hydrophyte are 'tals', 'nalas' and other water reservoir with low-lying areas. Most of the 'tals' and the Parvatiaranga lakes in the area hold water throughout the year, only a few smaller and less deeper ones may dry up during summer season. During rainy season these get filled with water as a part of Saryu river flood area. As the flood water recedes, these water bodies get roofed with a number of hydrophytes viz. Eichhornia crassipes (Mart.) Solms, Hygroryza aristata (Retz.) Nees ex Wight \& Arn., Pistia stratiotes L. \& Spirodela polyrrhiza (L.) Schleid., Ceratophyllum demersum L., Hydrilla verticillata (L.f.) Royle, Najas graminea Delile, Nechamandra alternifolia (Roxb. ex Wight) Thwaites, Ottelia alismoides (L.) Pers., Potamogeton crispus L., Nelumbo mucifera Gaertn., Nymphaea nouchali Burm.f., Nymphoides indica (L.) Kuntze., Ipomoea aquatica Forssk., Ludwigia adscendens (L.) Hara, Bacopa monnieri (L.) Wettst., Hygrophila auriculata (Schumach.) Heine, Phragmitis karka (Retz.) Trin. ex Steud., Ranunculus sceleratus L., Rumex dentatus L., Typha angustifolia L. and Veronica anagallis-aquatica L.

\section{B. Vegetation of Special Habitats}

The study area is also harbours a rich population of flora with special habitats. There are almost 5 categories (Fig. 3) of special habitats have been observed along with aquatic flora under which the species from the unique and characteristic phytoassociation forms the habitat conditions.

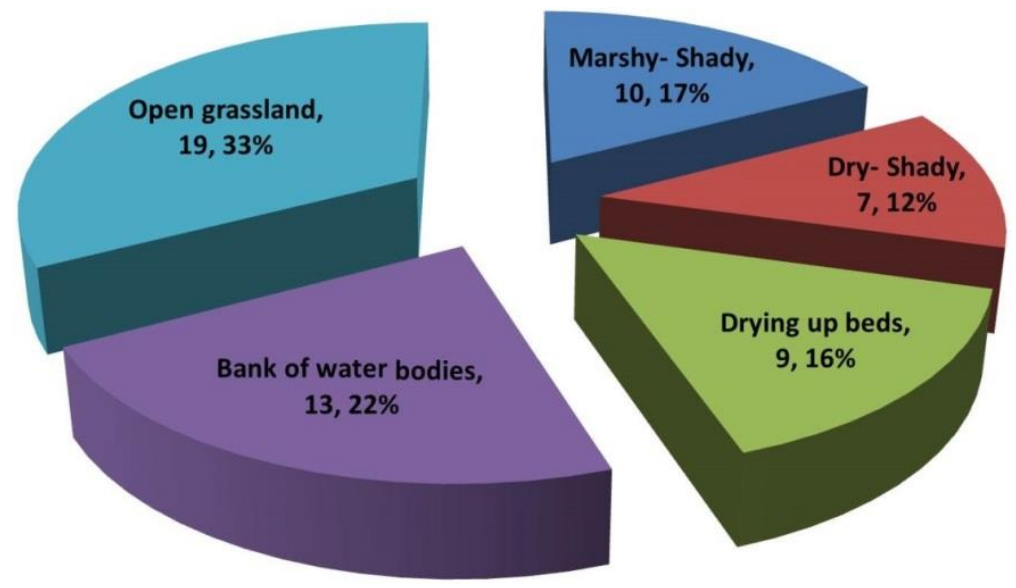

Figure 3. Frequency and percentage of vegetation of special habitats.

1. On marshy shady conditions: Under this situation the following phytoassociates are growing together viz. Bacopa monnieri (L.) Wettst., Centella asiatica (L.) Urb., Oldenlandia corymbosa L., Laphangium luteoalbum (L.) Tzvelev,. Ceratopteris thalictroides (L.) Brongn.,Pycreus pumilus (L.) Nees, Peperomia pellucida (L.) Kunth, Ranunculus muricatus L. and R. scleratoides Perfil. ex Ovczinn.

2. On dry shady situations: In these conditions scattered poulation of Abutilon indicum (L.) Sweet, Desmodium gangeticum (L.) DC., Phyllodium pulchellum (L.) Desv., Leea indica (Burm.f.) Merr., Scoparia dulcis L., Aerva sanguinolenta (L.) Blume and Ageratum conyzoides (L.) L. associations.

3. On drying up beds: In such areas plant species forming large clumps and patches under these associates viz. Coldenia procumbens L., Glinus lotoides L., Grangea maderaspatana (L.) Poir., Heliotropium supinum L., Polycarpon prostratum (Forssk.) Aschers \& Schweinf., Polygonum plebeium R. Br., Rumex dentatus L. and Sphaeranthus indicus L.

4. On the bank of water bodies: The following important plants and their associates are observed under this situation viz. Ammannia baccifera L., Lippia javanica (Burm.f.) Spreng., Chrysopogon zizaniodes (L.) Roberty, Arundo donax L., Typha domingensis Pers., Persicaria lapathifolia (L.) Delarbre species. There are also some woody species found along the water bodies in the forest area viz. Barringtonia acutangula (L.) Gaertn., Syzygium cumini (L.) Skeels, S. salicifolium (Wight) J. Graham and Pongamia pinnata(L.) Pierre along with other associates like Oxystelma secamone K. Schum., Tiliacora racemosa Colebr. and Vitex negundo L.

5. On open situations: These conditions support a rich wealth of grasslend flora with some woody species viz. Alangium salvifolium (L.f.) Wang subsp. decapetalum (Lam.) Wang, Alysicarpus monilifer (L.)DC., Apluda mutica L., Biophytum sensitivum (L.) DC., Boerhavia diffusa L., Bothriochloa pertusa (L.) A. Camus, Carissa spinarum L., Chrozophora rotleri A. Juss.Dalz., Clerodendrum infortunatum L., Cynodon dactylon (L.) Pers., www.tropicalplantresearch.com 
Imperata cylindrica (L.) Raeusch., Indigofera linifolia (L.f.) Retz., Solanum virginianum L., Urena lobata L., Chrysopogon zizanioides (L.) Nash, Woodfordia fruticosa (L.) Kurz and Ziziphus nummularia (Burm.f.) Wight \& Arn.

Parasitic and Epiphytic associations

Along with general floral association some unique association in form of parasitic and epiphytic are also found in the area:

1. Cuscuta reflexa Roxb. found on a variety of host plants viz. Streblus asper Lour., Glycosmis pentaphylla Retz. DC., Ipomoea fistulosa Mart. ex Choisy, Vitex negundo L. and on Ziziphus spp.

2. Dendrophthoe falcata (L.f.) Ettingsh. on Bombax ceiba L., Butea monosperma (Lam.) Taub., Mangifera indica L., Dalbergia sissoo DC., Syzygium cumini (L.) Skeels at some places on Tectona grandis L.f. .

3. Vanda tessellata (Roxb.) Hook. ex G. Don mainly growing as an epiphytes on Madhuca longifolia (J. Koenig ex L.) J.F. Macbr., Tectona grandis L.f. and on Shorea robusta Gaertn. (Fig. 4).

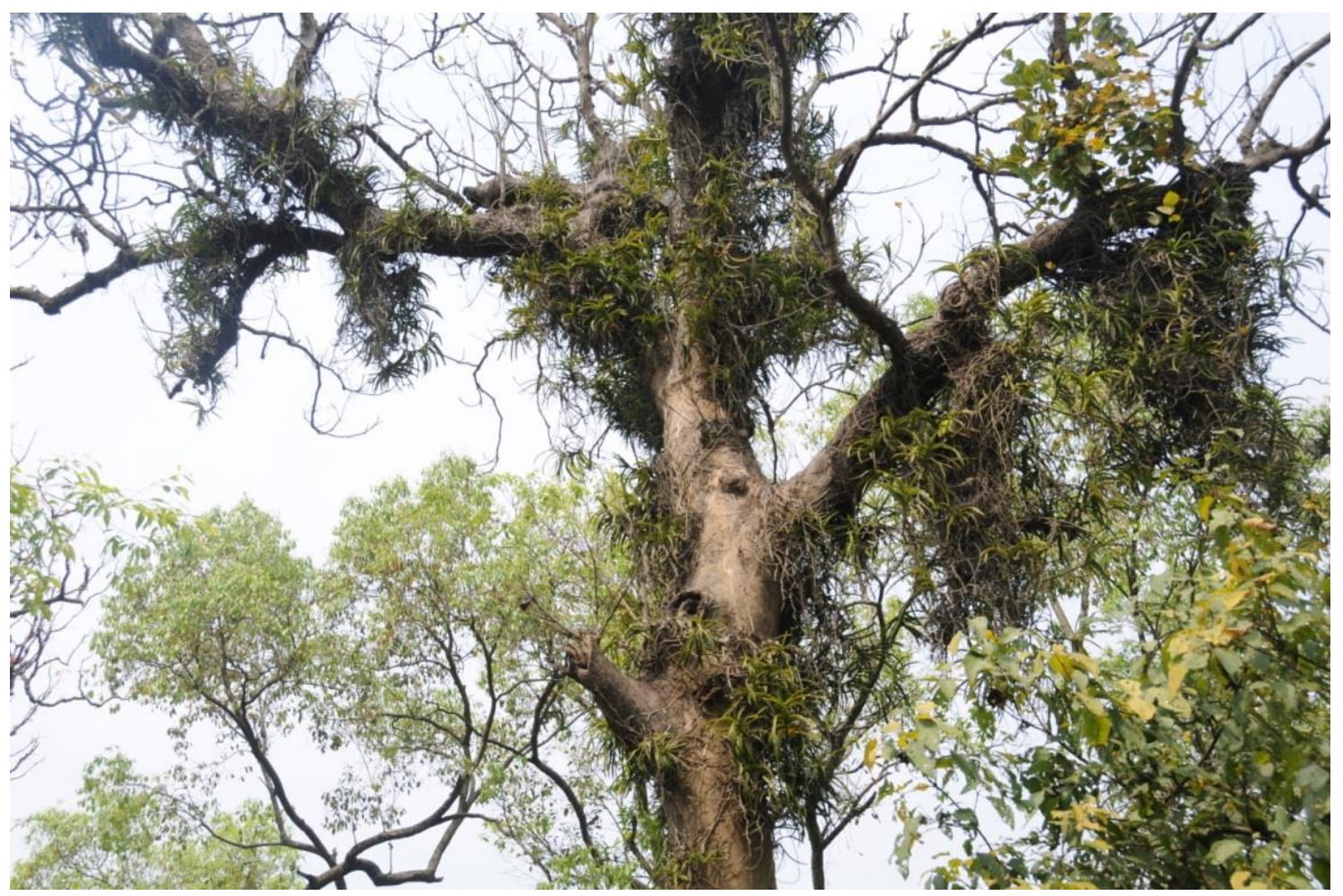

Figure 4. Epiphytic association of Vanda tessellata (Roxb.) Hook. ex G. Don on Madhuca longifolia (J. Koenig ex L.) J.F. Macbr.

Pattern of rareness and regeneration potential in the study area

Rarity and regeneration of plant species in any forest area plays a significant role in maintenance of a healthy forest. Plumbago zeylanica L., Oroxylum indicum (L.) Kurz., Hymenodictyon orixense (Roxb.) Mabb., Clerodendrum indicum (L.) Kuntze, Gloriosa superba L., Terminalia chebula Retz., Helicteres isoraL., Bauhinia vahlii Wight \& Arn., Bacopa monnieri (L.) Wettst., Leea alata Edgew., Habenaria plantaginea Lindl., Tylophora indica (Burm.f.) Merr., Cheilocostus speciosus (J. Koenig) C. D. Specht, Holarrhena pubescens Wall. ex G.Don, Heminthostachys zeylanica were considered most rare plant species found during collection and survey of the area (Table. 1). There are also some common specious occurs frequently in the entire area due to their capacity to produce seedling rapidly viz. Bridelia retusa (L.) A.Juss., Mallotus philippensis (Lam.) Mull. Arg., Mitragyna parvifolia (Roxb.) Korth., Terminalia alata Wall., Rotheca serrata (L.) Steane \& Mabb., Clerodendrum infortunatum L., Cayratia trifolia (L.) Domin, Cissampelos pareira L., Ichnocarpus frutescens (L.) W. T. Aiton, Elephantopus scaber L.and Lygodium flexuosum (L.) Sw (Table. 2). Certain rhizomatous species like Curculigo orchioides Gaertn., Typhonium trilobatum (L.) Schott, Helminthostachys zeylanica (L.) Hook. and Gloriosa superba L. growing even in highly stochastic environment. This type of rarity and regeneration among various species are indicative of their ability to reproduce and establish effiently in frequently distributed environment (Shukla 2009).

www.tropicalplantresearch.com 
Table 1. Rare species occurring in the study area.

\begin{tabular}{llll}
\hline Name of the species & Family & Habit & Phenology \\
\hline Bacopa monnieri (L.) Wettst & Plantaginaceae & Herbs & July-March \\
Bauhinia vahlii Wight \& Arn. & Leguminosae & Lianas & Sept--Jan. \\
Clerodendrum indicum (L.) Kuntze & Verbenaceae & Shrubs & April-Dec. \\
Cheilocostus speciosus (J. Koenig) C.D. Specht & Costaceae & Shrubs & Aug.-Jan. \\
Gloriosa superba L. & Liliaceae & Climbers & July-Nov. \\
Habenaria plantaginea Lindl. & Orchidaceae & Herbs & Aug.-Nov. \\
Helminthostachys zeylanica (L.) Hook. & Ophioglossaceae & Herbs & Oct.-Jan. \\
Holarrhena pubescens Wall. ex G.Don & Apocynaceae & Large Shrubs & May-Feb. \\
Hymenodictyon orixense (Roxb.) Mabb. & Rubiaceae & Trees & July-Feb. \\
Leea alata Edgew. & Vitaceae & Shrubs & June-Sept. \\
Oroxylum indicum (L.) Kurz. & Bignoniaceae & Trees & June-March \\
Passiflora foetida L. & Passifloraceae & Climbers & Nov.-Jan. \\
Plumbago zeylanica L. & Plumbaginaceae & Shrubs & Aug.-Oct. \\
Schleichera oleosa (Lour.) Merr. & Sapindaceae & Trees & April-Aug. \\
Strychnos nux - omica L. & Loganiaceae & Trees & March-Feb. \\
Terminalia chebula Retz. & Combretaceae & Trees & March-Oct. \\
Tylophora indica (Burm.f.) Merr. & Apocynaceae & Climbers & May-Sept. \\
\hline
\end{tabular}

Table 2. Most common species occurring in the study area.

\begin{tabular}{|c|c|c|c|}
\hline Name of the species & Family & Habit & Phenology \\
\hline Aerva sanguinolenta (L.) Blume & Amaranthaceae & Herbs & July-April \\
\hline Bridelia retusa (L.) A.Juss. & Phyllanthaceae & Trees & July-March \\
\hline Cayratia trifolia (L.) Domin & Vitaceae & Climbers & Aug.--Nov. \\
\hline Cissampelos pareira $\mathrm{L}$. & Menispermaceae & Climbers & June-Dec. \\
\hline Rotheca serrata (L.) Steane & Lamiaceae & Shrubs & Aug.-Oct. \\
\hline Clerodendrum infortunatum $\mathrm{L}$. & Lamiaceae & Shrubs & March-June \\
\hline Phyllodium pulchellum (L.) Desv. & Leguminosae & Shrubs & Aug. -April \\
\hline Dioscorea bulbifera $\mathrm{L}$. & Dioscoreaceae & Climbers & June-Nov. \\
\hline Elephantopus scaber L. & Asteraceae & Herbs & Jan.-March \\
\hline Glycosmis pentaphylla (Retz.) DC. & Rutaceae & Shrubs & Dec.-March \\
\hline Hemidesmus indicus (L.) R.Br. ex Schult. & Apocynaceae & Climbers & Aug.-Jan. \\
\hline Holoptelea integrifolia Planch. & Ulmaceae & Trees & Dec.-April \\
\hline Ichnocarpus frutescens (L.) W.T. Aiton & Apocynaceae & Climbers & July-Feb. \\
\hline Mallotus philippensis (Lam.) Mull. Arg. & Euphorbiaceae & Small trees & Oct.-May \\
\hline Mitragyna parviflora (Roxb.) Korth. & Rubiaceae & Trees & Sept.-Jan. \\
\hline Streblus asper Lour. & Moraceae & Trees & May-Sept. \\
\hline Terminalia alata Wall. & Combretaceae & Trees & April-Nov. \\
\hline
\end{tabular}

An extensive ecological and floristic study has been conducted in the north-eastern terai region of the Uttar Pradesh with respect to the floral diversity and documentation of vegetational phytosociology. The present communication reveals that the plant community with special habitat specially in protected and reserve forest area may plays a vital role in the future sustenance of the forest vegetation. The area also harbours a rich diversity of economical and medicinal plant species, mainly confined to the peripheral region of the forests. There is need of continued monitoring of various ecological parameters with the help of more accurate and sophasticated ecological tools for the betterment of the plant community of the study area.

\section{ACKNOWLEDGEMENTS}

The authors are thankful to Director, Botanical Survey of India, Kolkata and Scientist- 'E' and Head of Office, BSI, CRC, Allahabad for facilities and encouragement. The authors are also grateful to Range Officers and field staffs of Parvati Aranga Wildlife Sanctuary and Tikri reserve forest, Gonda for providing necessary help during field exploration. The authors are thankful to the Head, Department of Botany, D.S.B. campus, 
Kumaon University, Nainital for valuable suggestions.

\section{REFERENCES}

Bajpai O, Kumar A, Srivastava AK, Kushwaha AK, Pandey J \& Chaudhary LB (2015a) Trees species of the Himalayan Terai region of Uttar Pradesh, India: a Checklist. Checklist 11(4): 1-15.

Bajpai O, Kushwaha AK, Srivastava AK, Pandey J \& Chaudhary LB (2015b) Phytosociological status of a monotypic genus Indopiptadenia: A Near Threatened Tree from the Terai-Bhabar Region of Central Himalaya. Research Journal of Forestry 9(2): 35-47.

Bajpai O, Kumar A, Mishra AK, Sahu N, Pandey J, Behera SK \& Chaudhary LB (2012b) Recongregation of tree species of Katerniaghat Wildlife Sanctuary, Uttar Pradesh, India. Journal of Biodiversity and Environmental Sciences 2: 24-40.

Bajpai O, Kumar A, Mishra AK, Sahu N, Behera SK \& Chaudhary LB (2012a) Phenological study of two dominant tree species in tropical moist deciduous forest from the Northern India. International Journal of Botany 8: 66-72.

Behera SK, Mishra AK, Sahu N, Kumar A, Singh N, Kumar A, Bajpai O, Chaudhary LB, Khare PB \& Tuli R (2012) The study of microclimate in response to different plant community association in tropical moist deciduous forest from northern India. Biodiversity and Conservation 21(5): 1159-1176.

Braun-Blanquet J (1932) Plant Sociology- The Study of plant communities, London.

Champion HG \& Seth SK (1968) A revised survey of the forest Types of India. Manager of Publication, Govt. of India, New Delhi.

Chauhan DS, Dhanai CS, Singh B, Chauhan S, Todaria NP \& Khalid MA (2008) Regeneration and tree diversity in natural and planted forests in a Terai- Bhabhar forest in Katarniaghat wildlife sanctuary, India. Tropical Ecology 49: 53-67.

Duthie JF (1903-1929) Flora of Upper Gangetic Plain and Adjacent Siwalik and Sub-Himalayan Tracts. Vols 1-3. Rep. 1994.Bishen Singh Mahendra Pal Singh, Dehradun.

Gairola S, Rawal RS \& Todaria NP (2008) Forest vegetation pattern along an altitudinal gradient in sub-alpine zone of West Himalaya, India. African of Plant Science 2(6): 42-48.

Hooker JD (1872-1897) The Flora of British India. Bishensingh Mahendra Pal Singh, Dehradun India.

Jain SK \& Rao RR (1978) A Handbook of Field and Herbarium Methods. Today and Tomorrow 's Pub. New Delhi.

Kumar A, Bajpai O, Mishra AK, Sahu N, Behera SK, Bargali SS \& Chaudhary LB (2015) A checklist of the flowering plants of Katerniaghat Wildlife Sanctuary, Uttar Pradesh, India. Journal of Threatened Taxa 7(7): 7309-3408.

Maliya SD (2007) Rare species of Katarniyaghat Wildlife sanctuary District Bahraich, Uttar Pradesh, India. Indian Forester 133(8): 1052-1056.

Pandey SK \& Shukla RP (2003) Plant diversity in managed sal (Shorea robusta Gaertn.) forests of Gorakhpur, India: species composition, regeneration and conservation. Biodiversity and Conservation 12: 2295-2319.

Panigrahi G Singh AN Mishra OP (1969) Contribution to the botany of the terai forest of the Bahraich District of Uttar Pradesh.Bulletin of the Botanical Survey of India 11(1\&2): 89-114

Rodgers WA \& Sawarkar VB (1988) Vegetation management in Wildlife Protected Areas in India. Aspects of Applied Biology 16: 407-422.

Santapau H (1958a) Floriistic study in India.Mem. Indian Botanical Society 1: 117-121

Shukla RP (2009) Patterns of plant species diversity across Terai landscape in north-eastern Uttar Pradesh, India. Tropical Ecology 50(1): 111-123.

Singh V \& Srivastava SK (2014) Utilization of Wild Plants during Tinchhath festival in eastern Uttar Pradesh. Ethnobotany 26(1\&2): 101-103.

Singh V \& Srivastava SK (2015) A note on occurrence and copious growth of Helminthostachys zeylanica (L.) Hook. (Ophioglossaceae) in Tikri forest in Terai region, Uttar Pradesh. Phytotaxonomy 15: 15-16.

Singh V (2015) Rare Sighting of Nearly Threatened Grey-Headed Fish-Eagle Icthyophaga Ichthyaetus (Horsfield, 1821) From Tikri Reserve Forest of Eastern Uttar Pradesh, India. Indian Forester 141(10): 11041105. 